\title{
Atmospheric Deposition Study in the Area of Kardzhali Lead-Zinc Plant Based on Moss Analysis
}

\author{
Gergana Hristozova1, Savka Marinova1, Lyudmila Pavlovna Strelkova², Zoya Goryainova², \\ Marina Vladimirovna Frontasyeva ${ }^{2 *}$, Trajče Stafilov ${ }^{3}$ \\ ${ }^{1}$ Faculty of Physics and Engineering Technologies, Paisii Hilendarski University, Plovdiv, Bulgaria \\ ${ }^{2}$ Department of Neutron Activation Analysis and Applied Research, Division of Nuclear Physics, Frank \\ Laboratory of Neutron Physics, Joint Institute for Nuclear Research, Moscow, Russia \\ ${ }^{3}$ Institute of Chemistry, Faculty of Science, Sts. Cyril and Methodius University, Skopje, Macedonia \\ Email: marina@nf.jinr.ru
}

Received 23 July 2014; revised 10 September 2014; accepted 27 September 2014

Copyright (C) 2014 by authors and Scientific Research Publishing Inc.

This work is licensed under the Creative Commons Attribution International License (CC BY). http://creativecommons.org/licenses/by/4.0/

(c) (i) Open Access

\begin{abstract}
For the first time the moss biomonitoring technique was used to assess the environmental situation in the area affected by a lead zinc plant as one of the most hazardous enterprises in Bulgaria. 77 Hypnum cupressiforme moss samples were collected in the Kardzhali municipality, in the summer and autumn of 2011. The concentrations of a total of 47 elements were determined by means of instrumental epithermal neutron activation analysis (ENAA), atomic absorption spectrometry (AAS) and inductively coupled plasma-atomic emission spectrometry (ICP-AES). Multivariate statistics was applied to characterize the sources of elements detected in the samples. Four groups of elements were found. In comparison to the data averaged for the area outside of the town, the atmospheric deposition loads for the elements of industrial origin in Kardzhali, where the smelter chimney is located, were found to be much higher. Median levels of the measured concentrations for the most toxic metals ( $\mathrm{Pb}, \mathrm{Zn}, \mathrm{Cd}, \mathrm{As}, \mathrm{Cu}$, In, Sb) were extremely high in this hot spot when compared to the median Bulgarian cross-country data from the $2010 / 2011$ European moss survey. GIS technology was used to produce element distribution maps illustrating deposition patterns of element pollutants in the study area. The results obtained contribute to the Bulgarian environmental research used to study and control the manufacturing processes of a lead-zinc smelter in the town of Kardzhali.
\end{abstract}

\section{Keywords}

Moss Biomonitoring, Heavy Metals, Epithermal Neutron Activation Analysis, Atomic Absorption Spectrometry

\footnotetext{
${ }^{*}$ Corresponding author.

How to cite this paper: Hristozova, G., Marinova, S., Strelkova, L.P., Goryainova, Z., Frontasyeva, M.V. and Stafilov, T. (2014) Atmospheric Deposition Study in the Area of Kardzhali Lead-Zinc Plant Based on Moss Analysis. American Journal of Analytical Chemistry, 5, 920-931. http://dx.doi.org/10.4236/ajac.2014.514100
} 


\section{Introduction}

Mosses have been used as biomonitors for assessment of heavy metal atmospheric deposition since the late 1960's [1]. This technique is an adequate method of air pollution evaluation due to a negligible uptake from the moss substrate; nutrients are primarily obtained by means of dry and wet deposition. Certain morphological and physiological properties of the mosses (e.g. large cationic exchange properties within the cell wall, lack of advanced root system and cuticles) make them appropriate biomonitors [2]. Several moss species are suitable for time-integrated assessment of present state environmental contamination due to the fact that annual growth increments can be easily separated for analysis. In addition, the abundance and large geographical distribution of mosses is advantageous and provides for an inexpensive and simple alternative to conventional bulk deposition analysis. Thus, a high density network of sampling sites is easily achieved. This allows for pollution distribution maps to be produced.

Large-scale monitoring utilizing the moss technique was first introduced in Scandinavian countries four decades ago [3]. The Environmental Monitoring and Data Group in the Nordic countries extended an invitation to other European nations in the late 1980's and in 1990 the first European-scale survey was conducted [4]. The survey has been carried out at intervals of five years since. Standardized protocols and reference materials have been acknowledged. The species Pleuzorium schreberi, Hylocomium splendens, Hypnum cupressiforme and Pseudoscleropodium purum have been used in the monitoring programme to study temporal and spacial trends of deposition [5]. A decrease in the concentrations of all reported pollutants (As, $\mathrm{Cd}, \mathrm{Cr}, \mathrm{Cu}, \mathrm{Fe}, \mathrm{Pb}, \mathrm{Hg}, \mathrm{Ni}, \mathrm{V}$, $\mathrm{Zn}$ ) has been observed since the start of the survey. Generally, the highest concentrations were found in southeastern Europe [6].

The present study is focused on an area in the vicinity of a lead-zinc plant in Kardzhali, Bulgaria (Figure 1). Based on State Energy and Water Regulatory Commission (SEWRC) data, it is a major source of pollution emissions that affect air quality and also have a direct effect on the health of the population [7].

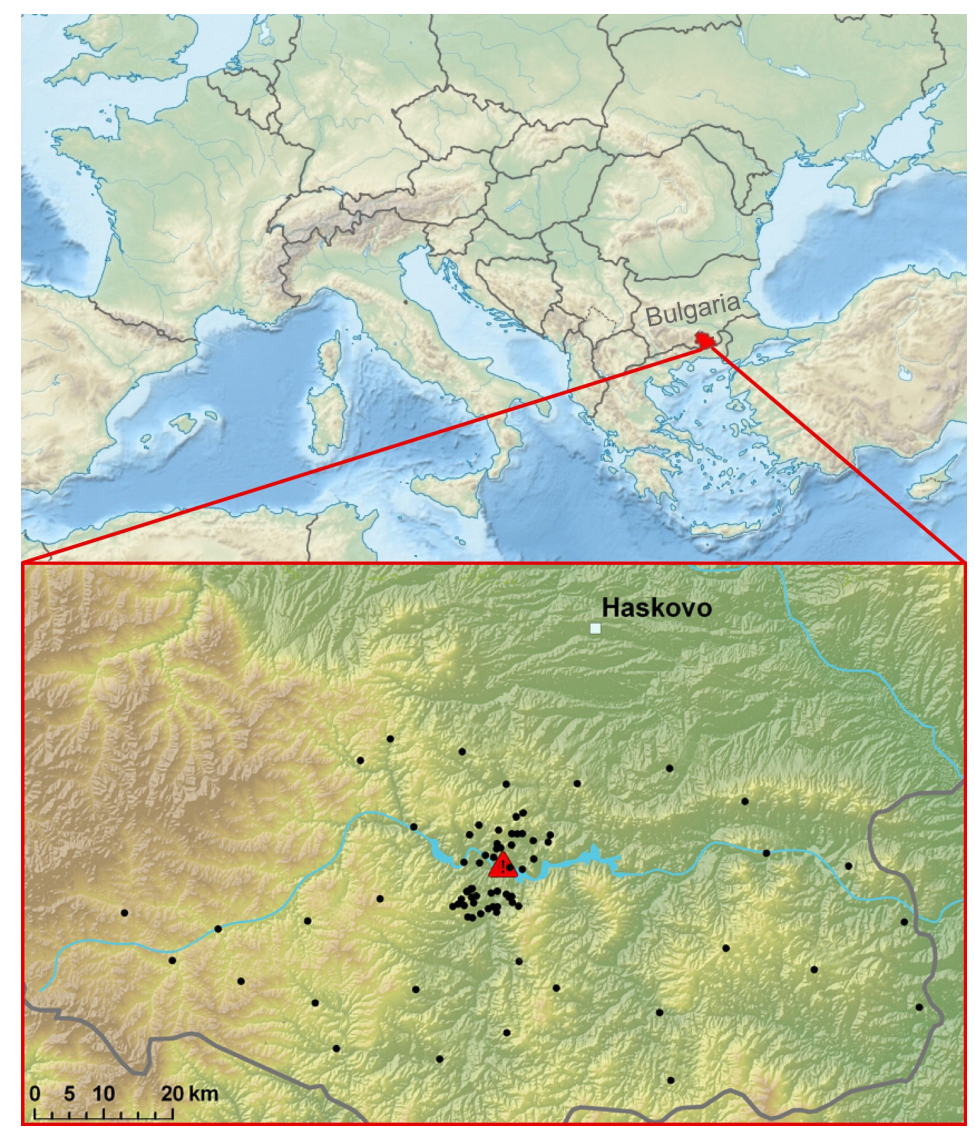

Figure 1. Study area. Sampling sites marked by black dots, red exclamation sign identifies the position of the smelter chimney. 
The smelter, "Lead-Zinc Complex" (LZC) Plc., is situated in the industrial part of Kardzhali town, on the northern shore of the Studen Kladenets pond. It began operating in 1955, producing 5000 tons of zinc and 7000 tons of sulfuric acid annually. Lead and alloys production began in 1956, followed by zinc sulfate, bismuth, cadmium, sodium bisulfite, zinc alloys, lead-antimony alloys production as well as the processing of exhausted batteries, selenium and calcium-cadmium alloys used in the battery industry, and others [8]. The lead-zinc plant is famous for the production of nonferrous metals and is a major source of contamination. By the end of 2009 there had been multiple investment proposals and programs to increase production and efficiency, improve energy recovery and environmental conditions, and to replace the existing equipment. Nevertheless, due to delays in the implementation of new technology, the facility's operation has inflicted environmental damage to the region with regular emissions of sulfur dioxide, heavy metals and other toxic elements (e.g. $\mathrm{Pb}, \mathrm{Zn}, \mathrm{Cd}, \mathrm{As}$ ), which are deposited from the air to the soil and water. The town of Kardzhali is considered to be one of the pollution hotspots in Bulgaria [9].

Within Kardzhali municipality pollutants have frequently been above the standards in place for atmospheric air quality in Bulgaria. The number of days with fog and calm weather predetermine the poor dispersion of local pollutants and therefore their increased concentration. Heat, light and moisture distribution are affected by the region's particularities of the relief, topography, altitude, inclination and wind rose [10].

The regulatory bodies for atmospheric air quality in Kardzhali municipality are the Ministry of Environment and Water, and Haskovo regional laboratory. Control data are obtained using an automated air quality monitoring station in Studen Kladenets, working since 2008. It registers the levels of several air quality indices: fine dust particles, $\mathrm{SO}_{2}$, lead aerosols, As, $\mathrm{Cd}$ and polycyclic aromatic hydrocarbons. The data obtained is related to the operation of the lead-zinc complex "LZC" and to the stock companies "Gorubso-Kardzhali" (tailings in particular), "Bentonid" and "S \& B Industrial Minerals" [7]. The results are used to impose ecological measures, establish appropriate working and storage conditions, suggest improvements or replacements of old equipment and call for a temporary shutting down of the production processes, which took place in 2011 [11].

Subsequently, the reported values for $\mathrm{Cd}, \mathrm{Pb}$, and $\mathrm{As}$, measured by the monitoring station in Studen Kladenets in 2012 did not exceed the average annual standard [7].

The objective of this study was to determine the concentration of elements in mosses obtained in an environmental hot spot and the surrounding area. The results were anticipated to be an expansion to the available data on a small number elements investigated by the State regulatory bodies. Multivariate statistics and GIS technology were used to classify data and to appoint possible sources of the element pollutants and their deposition patterns.

\section{Methods and Materials}

\subsection{Study Area}

The moss species Hypnum cupressiforme was used as boimonitor to study an area of about $6000 \mathrm{~km}^{2}$ located primarily on the territory of the Kardzhali municipality. It spans $30 \mathrm{~km}$ to the north and south, and $55 \mathrm{~km}$ to the west and east from the smelter's chimney.

A total of 77 moss samples were obtained in the summer and autumn of 2011. The sampling strategy of the UNECE ICP Vegetation Programme on atmospheric deposition studies in Europe (United Nations Economic Commission for Europe, International Coopeative Programme on Effects of Air Pollution on Natural Vegetation and Crops) has been observed, with the exception of the recommended sampling network density. It was altered due to the relatively small study area.

From each site 5 - 10 subsamples were taken within a $1 \times 1 \mathrm{~km}$ area and were combined on field. Random samples outside the sampling network were also collected. In the town of Kardzhali, sampling density was higher. The sampled area is presented in Figure 1. Using GPS, longitude and latitude were noted for all sampling sites. All collected samples were put into plastic bags for storage and transportation to the analytical laboratories.

\subsection{Analysis}

\subsubsection{NAA}

NAA was performed in the radioanalytical laboratory at the fast pulsed reactor IBR-2 of the Frank Laboratory of Neutron Physics, Joint Institute for Nuclear Research (FLNP JINR), Dubna, Russia. In the laboratory the un- 
washed samples were air-dried to constant weight at $40^{\circ} \mathrm{C}$ for $48 \mathrm{~h}$, and extraneous plant material was removed. Samples were sorted so that only the green living part of the moss, approximately corresponding to a three-year growth, was subjected to analysis. Moss samples of about $0.3 \mathrm{~g}$ were packed in polyethylene foil bags for shortterm irradiation and in aluminum cups for long-term irradiation [12].

Long term irradiation was performed using a cadmium-screened irradiation channel with neutron flux density $\Phi_{\text {epi }}=3.6 \times 10^{11} \mathrm{n} /\left(\mathrm{cm}^{2} \times \mathrm{s}\right)$ to determine long-lived isotopes. Samples were irradiated for 5 days, re-packed and then measured twice, after 4 - 6 days and 20 days of decay, respectively. The interval of measurement varied from 1 to $5 \mathrm{~h}$. To determine the short lived isotopes ( $\mathrm{Cl}, \mathrm{V}, \mathrm{I}, \mathrm{Mg}, \mathrm{Al}$, and $\mathrm{Mn}$ ) a conventional irradiation channel was used. Samples were irradiated for 3 min and measured twice, after 2 - 3 min and 9 - 10 min of decay. Data processing was carried out using software developed at FLNP JINR. Qualitative and quantitative analysis were conducted on the basis of certified reference materials and flux comparators.

Quality Control

Three certified reference materials were used to conduct quality control: (RM) Lichen 336 IAEA (International Atomic Energy Agency), SRM-1575 (Pine Needles) from the US National Institute of Standards and Technology, and moss DK-1, prepared for calibration of laboratories participating in the 1990 moss survey in Northern Europe. The reference materials were packed together with the samples in each transport container. The reference material showing least deviation between measured and certified values of elemental content was chosen.

\subsubsection{ICP-AES and AAS}

ICP-AES and AAS were carried out at the Sts. Cyril and Methodius University, Skopje, Macedonia. Atomic emission spectrometer with inductively coupled plasma, ICP-AES (Varian, 715ES), was used for analyzing the content of $\mathrm{Ag}, \mathrm{Cd}, \mathrm{Cu}, \mathrm{Li}, \mathrm{P}$, and $\mathrm{Pb}$. ICP-Multielement standard solution IV (Merck) with concentration of $1000 \mathrm{mg} \cdot \mathrm{L}^{-1}$ was used for preparation of standard solutions. Mercury was determined by cold vapor AAS (Varian, SpectrAA 55B), using a continuous flow vapor generation accessory (Varian, VGA-76).

For ICP-AES and AAS analysis about $0.5 \mathrm{~g}$ of moss material was placed in Teflon vessel and treated with 7 ml of concentrated $\mathrm{HNO}_{3}$ and $2 \mathrm{ml} \mathrm{H}_{2} \mathrm{O}_{2}$ overnight. The procedure was continued with full digestion of moss material in microwave digestion system (Mars, CEM, USA). Digestion was carried out in two steps: 1) ramp: temperature $180^{\circ} \mathrm{C}, 10$ min ramp time, power of $400 \mathrm{~W}$ and pressure $20 \mathrm{bar}$; 2) hold: temperature $180^{\circ} \mathrm{C}, 20 \mathrm{~min}$ hold time, power of $400 \mathrm{~W}$ and pressure 20 bar. Digests were filtrated and quantitatively transferred to $25 \mathrm{ml}$ calibrated flasks [13].

Quality Control

The QC/QA of the applied techniques was performed by standard addition method, and it was found that the recovery for the investigated elements ranges for ICP-AES from $98.5 \%$ to $101.2 \%$, for ETAAS and CVAAS from $96.9 \%$ to $103.2 \%$. The same methods were applied for the determination of the analyzed elements in certificated reference materials M2 and M3 (moss samples). The sensitivity in regard to the lower limit of detection was done. Optimization of instrumental condition for analyzed elements was previously done [14]. Beside standard addition method, blanks parallel to the decomposition of samples and preparation of sample solutions for analysis were analyzed. The loss of Hg was checked by standard additions. The same sample was decomposed with and without addition of Hg. The added content of Hg was recovered in the solution obtained after microwave digestion [15].

\section{Results and Discussion}

Table 1 contains descriptive data (median, minimum and maximum values) from the present analyses, corresponding Bulgarian data from the 2010 European moss survey, concentration values from a similar lead-zinc mine area in Macedonia (samples collected in 2012 and analysis performed using ICP-AES, ETAAS and CVAAS) [16], and comparison data from Norway (2007, utilizing ICP-MS) [20], where the influence of air pollution is considered minor.

The juxtaposition of the data clearly illustrates that for the vast majority of elements, concentrations in the Kardzhali Municipality are the highest. Exceptions from this observation are only the median and maximum values for $\mathrm{Mg}$, which are the lowest, even in comparison with the Norwegian data [20]. The median values for $\mathrm{Pb}, \mathrm{Cd}, \mathrm{Zn}$, and $\mathrm{Al}$ greatly exceed the averaged median in Bulgaria (by factors of about 16, 9, 8, and 13 respectively) and in the Macedonian lead-zinc mine (by factors of 5, 6, 5, and 6 respectively). When comparing the 
Table 1. Descriptive statistics of elements determined in mosses obtained in Kardzhali Municipality, Macedonian mine environ and data from moss surveys in Bulgaria and Norway $(\mathrm{mg} / \mathrm{kg})$.

\begin{tabular}{|c|c|c|c|c|c|c|c|c|}
\hline \multirow[t]{2}{*}{ Elements } & \multicolumn{2}{|c|}{$\begin{array}{l}\text { Kardzhali Municipality } \\
\text { (present study) }\end{array}$} & \multicolumn{2}{|c|}{$\begin{array}{c}\text { Macedonian Pb-Zn } \\
\text { mine environ } 2012 \text { [16] }\end{array}$} & \multicolumn{2}{|c|}{ Bulgaria 2010 [6] } & \multicolumn{2}{|c|}{ Norway 2005 [20] } \\
\hline & Median & Range & Median & Range & Median & Range & Median & Range \\
\hline $\mathrm{Li}^{\mathrm{a}}$ & 1.49 & $0.51-8.06$ & 1.1 & $0.31-3.9$ & & & & \\
\hline $\mathrm{Na}$ & 1320 & $179-9710$ & 41 & $20-890$ & & & & \\
\hline $\mathrm{Mg}$ & 943 & $366-3740$ & 3200 & $1700-4800$ & & & 1730 & $940-2370$ \\
\hline $\mathrm{Al}$ & 16300 & $4120-76,400$ & 2500 & $680-13000$ & 1245 & $402-8886$ & 200 & $67-820$ \\
\hline $\mathrm{P}^{\mathrm{a}}$ & 988 & 405 - 1831 & 770 & $410-1500$ & & & & \\
\hline $\mathrm{Cl}$ & 160 & $77.10-601$ & & & & & & \\
\hline K & 7250 & $3650-30,900$ & 4600 & $2000-9800$ & & & & \\
\hline $\mathrm{Ca}$ & 11400 & $5520-21,700$ & 6500 & $2900-14,000$ & & & 2820 & $1680-5490$ \\
\hline Sc & 2.25 & $0.12-13.00$ & & & & & 0.052 & $0.009-0.220$ \\
\hline $\mathrm{Ti}$ & 672 & $170-3990$ & & & & & 23.5 & $12.4-66.4$ \\
\hline $\mathrm{V}$ & 17.9 & $6.30-124$ & 3.1 & $0.76-9.7$ & 3.07 & $0.96-22.4$ & 0.92 & $0.39-5.1$ \\
\hline $\mathrm{Cr}$ & 13.3 & $2.71-260$ & 2.1 & $0.84-5.1$ & 2.06 & $0.72-38.1$ & 0.55 & $0.10-4.2$ \\
\hline $\mathrm{Mn}$ & 450 & $56-3380$ & 160 & $43-550$ & & & 256 & $22-750$ \\
\hline $\mathrm{Fe}$ & 5800 & $1250-32,400$ & 2500 & $820-18,000$ & 1101 & $307-8546$ & 209 & $77-1370$ \\
\hline Co & 2.47 & $0.43-23.50$ & 0.53 & $0.16-2.6$ & & & 0.202 & $0.065-0.654$ \\
\hline $\mathrm{Ni}$ & 9.48 & $1.4-213$ & 2.7 & $1.1-6.4$ & 2.61 & $0.84-82.1$ & 1.14 & $0.12-6.6$ \\
\hline $\mathrm{Cu}^{\mathrm{a}}$ & 13.69 & 7 - 126 & 7.2 & $3.6-57$ & 7.01 & 2 - 270 & & \\
\hline $\mathrm{Zn}$ & 185 & $25-3750$ & 36 & $11-460$ & 22.2 & $8.22-286$ & 26.5 & $7.9-173$ \\
\hline As & 2.83 & $0.48-22.40$ & 2 & $0.56-13$ & 0.63 & $0.15-10.8$ & 0.093 & $0.020-0.505$ \\
\hline Se & 0.43 & $0.07-2.54$ & & & & & 0.33 & $0.05-1.30$ \\
\hline $\mathrm{Br}$ & 6.42 & $1.66-19.50$ & & & & & 4.5 & $1.4-20.3$ \\
\hline $\mathrm{Rb}$ & 24.8 & $6.93-229$ & & & & & 7.7 & $1.3-51.5$ \\
\hline $\mathrm{Sr}$ & 71.2 & $19.50-527$ & 17 & $7.2-36$ & & & 15.8 & 3.6 - 43.3 \\
\hline Mo & 0.49 & $0.12-1.78$ & & & & & 0.135 & $0.065-0.70$ \\
\hline $\mathrm{Ag}^{\mathrm{a}}$ & 0.57 & $0.14-4.43$ & & & & & & \\
\hline $\mathrm{Cd}^{\mathrm{a}}$ & 1.85 & $0.19-21.11$ & 0.31 & $0.06-3.7$ & 0.21 & $0.043-7.75$ & & \\
\hline In & 0.05 & $0.0003-0.42$ & & & & & & \\
\hline $\mathrm{Sb}$ & 2.07 & $0.14-46.50$ & & & & & 0.033 & $0.004-0.240$ \\
\hline I & 2.18 & $0.90-7.71$ & & & & & 2.5 & $0.6-41.7$ \\
\hline Cs & 1.32 & $0.19-8.81$ & & & & & 0.072 & $0.016-0.88$ \\
\hline $\mathrm{Ba}$ & 164 & $35-1050$ & 45 & $11-140$ & & & 17.1 & $5.6-50.5$ \\
\hline $\mathrm{La}$ & 6.38 & $0.92-40.60$ & & & & & 0.189 & $0.045-2.56$ \\
\hline $\mathrm{Ce}$ & 14.50 & $1.67-91.30$ & & & & & 0.342 & $0.095-4.61$ \\
\hline $\mathrm{Nd}$ & 5.97 & $0.96-35.10$ & & & & & & \\
\hline $\mathrm{Sm}$ & 1.14 & $0.20-7.47$ & & & & & 0.33 & $0.05-1.34$ \\
\hline $\mathrm{Tb}$ & 0.15 & $0.03-0.94$ & & & & & 0.003 & $<0.002-0.030$ \\
\hline Dy & 0.95 & $0.03-6.24$ & & & & & & \\
\hline $\mathrm{Tm}$ & 0.11 & $0.02-0.63$ & & & & & & \\
\hline $\mathrm{Yb}$ & 0.53 & $0.04-2.624$ & & & & & & \\
\hline $\mathrm{Hf}$ & 0.93 & $0.21-7.62$ & & & & & & \\
\hline $\mathrm{Ta}$ & 0.18 & $0.04-1.38$ & & & & & 0.01 & $<0.01-0.07$ \\
\hline $\mathrm{W}$ & 0.47 & $0.10-3.43$ & & & & & 0.127 & $0.009-1.23$ \\
\hline $\mathrm{Au}$ & 0.002 & $0.001-0.024$ & & & & & & \\
\hline $\mathrm{Hg}^{\mathrm{b}}$ & 0.05 & $0.03-0.14$ & 0.03 & $0.021-0.08$ & & & & \\
\hline $\mathrm{Pb}^{\mathrm{a}}$ & 124.85 & $4.21-2168$ & 24 & $0.14-450$ & 8 & $1.69-333$ & & \\
\hline Th & 2.70 & $0.24-21.60$ & & & & & 0.033 & $0.004-0.240$ \\
\hline $\mathrm{U}$ & 0.60 & $0.10-5.22$ & & & & & 0.015 & $0.001-0.138$ \\
\hline
\end{tabular}

adetermined by ICP-AES, betermined by AAS. 
maximum values for the same elements, the situation is similarly unfavorable. The content of $\mathrm{Na}$, Co, $\mathrm{Ni}$ and $\mathrm{Cr}$ in the Kardzhali mosses is considerably higher than in Macedonia [16].

It has to be noted that due to the methods applied, some differences in the results are anticipated. These arise from their different sensitivities and the fact that ICP-AES and AAS are both destructive methods based on acid digestion, so refractory compounds present in the samples cannot be analysed. NAA is a non-destructive method where the whole amount of the elements is detected.

Multivariate statistics (factor analysis) was used to identify and characterize different pollution sources. The Varimax method was used for orthogonal rotation of variables standardized to zero mean and unit standard deviation [17]. The number of elements was reduced to four synthetic variables or factors. The results are presented in Table 2. Factor analysis with Varimax rotation is an approved approach when utilizing the moss biomonitoring technique [18].

GIS maps for elemental distribution based on the results of factor analysis were built using AcrGIS 9.3 (Factors 1, 2, 3 and 4 on Figures 2-5, respectively). Factor scores illustrating the contributions of individual sampling sites to the relevant factor are shown graphically.

Factor 1: The rare earth elements $\mathrm{Hf}, \mathrm{Ta}, \mathrm{U}$, and Th are soil indicators, typical for heavy crustal material, and partly reflect the contamination of moss samples with soil particles. The high loadings for $\mathrm{Na}(0.83), \mathrm{Mg}(0.70), \mathrm{Al}$ (0.85), Sc (0.69), and Ti (0.71) represent light crustal material (silicate rocks), V (0.63) and Fe (0.79) could be attributed to a basaltic component. K (0.84), Rb (0.81), Sr (0.77), Mo (0.66), Cs (0.77), Ba (0.81) are most likely of vegetation origin.

Factor 2: The high loadings for $\mathrm{Cu}$ (0.90), Zn (0.94), As (0.68), Se (0.80), Ag (0.96), Cd (0.97), In (0.89), Sb (0.96), $\mathrm{Au}(0.63), \mathrm{Hg}(0.70)$, and $\mathrm{Pb}(0.98)$ in this factor characterize the Kardzhali LZP productions. This group of elements is also found in the investigation of surface soils around a lead and zinc smelter in the Republic of Macedonia [19].

For this factor, the highest factor score is observed on the sampling site closest to the smelter chimney.

When inspecting the data obtained on the territory of the town of Kardzhali, where the sampling network density is the highest, and comparing it with the averaged values determined for the exterior sites, disparities were observed. There is a significant difference between the obtained maximum, minimum and median values for the concentrations of the elements $\mathrm{Cu}, \mathrm{Zn}, \mathrm{Ag}, \mathrm{Cd}, \mathrm{In}, \mathrm{Sb}$, and $\mathrm{Pb}$ in and outside the town.

For $\mathrm{Pb}$, the maximum determined concentration in the territory of the town exceeds the maximum concentration measured in the vicinity by a factor of 55. Minimum and median values in Kardzhali exceed the corresponding values in the suburban area by a factor of 4 .

$\mathrm{Sb}$ content in the town has a maximum value 23 times higher than in the suburbs. The median value is higher by a factor of 10 and the minimum by a factor of 3 .

The maximum in concentration obtained from the town exceeds the corresponding value from the extra urban area by factor of 144. The minimum and median values are higher on the territory of the town by factor of 2 and 3 respectively.

Cd content in Kardzhali has a maximum value 13 times higher than the corresponding value for the vicinity. Minimum and median values are both 3 times higher in the town than outside of its territory.

The maximum determined Ag concentration from mosses obtained in Kardzhali, is 4 times higher than the Ag concentration in the extra urban area. The minimum and median values are higher in the town by a factor of 3 .

In the town, the maximum determined concentration for $\mathrm{Zn}$ is 7 times higher than the corresponding content outside of the town. The minimum and median values are higher in Kardzhali by a factor of 3 and 4, respectively.

The maximum and median values for the measured $\mathrm{Cu}$ content in the urban area are higher than the corresponding values determined in the suburbs by factor of 3 . The minimum value is 4 times higher in Kardzhali than in the extra urban area.

Factor 3: Contamination from metallurgical industry is associated with the high values for $\mathrm{V}(0.48), \mathrm{Cr}(0.84)$, $\mathrm{Co}(0.79)$, and $\mathrm{Ni}(0.85)$ in this factor. The studied area is rich in ore deposits and is characterized by extensive mining activities which took place in the past but have dwindled nowadays. The elemental deposition maps indicate such sites in the south-west and south-east of the plant (Figure 4).

The highest factor loadings for this factor are found in sampling sites located nearby an open quarry used for the production of building materials such as sand, rubble, and cement. The quarry is used for extraction of perlite, betonite (Na-Ca type), zeolite, marble, gneiss, tuff, limestone, and obsidian.

Factor 4: The combination of high values for $\mathrm{Cl}(0.60), \mathrm{Br}(0.73)$, and $\mathrm{I}(0.77)$ in one factor usually suggests a 
Table 2. Matrix of rotated factor scores, Varimax normalized. Four main source types identified. Characteristic elements marked in bold type.

\begin{tabular}{|c|c|c|c|c|}
\hline Variables & Factor 1 & Factor 2 & Factor 3 & Factor 4 \\
\hline $\mathrm{Li}$ & 0.52 & -0.10 & 0.39 & -0.15 \\
\hline $\mathrm{Na}$ & 0.83 & 0.12 & 0.16 & -0.10 \\
\hline $\mathrm{Mg}$ & 0.70 & -0.13 & 0.48 & 0.15 \\
\hline $\mathrm{Al}$ & 0.85 & -0.13 & 0.27 & 0.04 \\
\hline $\mathrm{P}$ & 0.03 & 0.15 & -0.09 & 0.59 \\
\hline $\mathrm{Cl}$ & 0.02 & 0.13 & -0.28 & 0.60 \\
\hline $\mathrm{K}$ & 0.84 & 0.19 & -0.14 & 0.19 \\
\hline $\mathrm{Ca}$ & 0.28 & -0.06 & -0.06 & 0.35 \\
\hline Sc & 0.69 & -0.15 & 0.35 & -0.05 \\
\hline $\mathrm{Ti}$ & 0.71 & -0.19 & 0.43 & -0.13 \\
\hline $\mathrm{V}$ & 0.63 & -0.09 & 0.48 & -0.20 \\
\hline $\mathrm{Cr}$ & 0.13 & 0.07 & 0.84 & 0.09 \\
\hline $\mathrm{Mn}$ & 0.23 & -0.18 & 0.21 & 0.47 \\
\hline $\mathrm{Fe}$ & 0.79 & -0.05 & 0.44 & -0.10 \\
\hline Co & 0.46 & 0.02 & 0.79 & 0.03 \\
\hline $\mathrm{Ni}$ & 0.08 & 0.08 & 0.85 & 0.09 \\
\hline $\mathrm{Cu}$ & 0.03 & 0.90 & -0.12 & -0.07 \\
\hline $\mathrm{Zn}$ & 0.05 & 0.94 & -0.02 & 0.05 \\
\hline As & 0.19 & 0.68 & 0.53 & 0.22 \\
\hline Se & -0.03 & 0.80 & 0.07 & 0.16 \\
\hline $\mathrm{Br}$ & -0.08 & 0.27 & 0.29 & 0.73 \\
\hline $\mathrm{Rb}$ & 0.81 & 0.14 & -0.11 & 0.32 \\
\hline $\mathrm{Sr}$ & 0.77 & 0.03 & -0.22 & 0.03 \\
\hline Mo & 0.66 & 0.42 & 0.13 & 0.23 \\
\hline $\mathrm{Ag}$ & 0.04 & 0.96 & 0.00 & -0.05 \\
\hline $\mathrm{Cd}$ & 0.08 & 0.97 & -0.04 & 0.05 \\
\hline In & 0.17 & 0.89 & 0.06 & 0.06 \\
\hline $\mathrm{Sb}$ & 0.06 & 0.96 & -0.08 & 0.02 \\
\hline I & 0.03 & 0.05 & 0.35 & 0.77 \\
\hline Cs & 0.77 & 0.09 & -0.1 & 0.30 \\
\hline $\mathrm{Ba}$ & 0.81 & 0.03 & 0.05 & 0.05 \\
\hline $\mathrm{La}$ & 0.89 & 0.12 & 0.21 & 0.02 \\
\hline $\mathrm{Ce}$ & 0.92 & 0.14 & 0.20 & 0.05 \\
\hline $\mathrm{Nd}$ & 0.77 & 0.30 & 0.09 & 0.04 \\
\hline $\mathrm{Sm}$ & 0.93 & 0.04 & 0.18 & 0.02 \\
\hline $\mathrm{Tb}$ & 0.89 & 0.08 & 0.25 & -0.03 \\
\hline Dy & 0.81 & -0.06 & 0.31 & -0.03 \\
\hline $\mathrm{Tm}$ & 0.62 & 0.11 & 0.54 & -0.03 \\
\hline $\mathrm{Yb}$ & 0.89 & 0.06 & 0.23 & 0.05 \\
\hline $\mathrm{Hf}$ & 0.90 & 0.09 & 0.16 & -0.04 \\
\hline $\mathrm{Ta}$ & 0.88 & 0.05 & -0.03 & 0.24 \\
\hline W & 0.78 & 0.10 & 0.07 & 0.18 \\
\hline $\mathrm{Au}$ & 0.07 & 0.63 & 0.15 & 0.11 \\
\hline $\mathrm{Hg}$ & 0.12 & 0.70 & -0.07 & 0.45 \\
\hline $\mathrm{Pb}$ & 0.06 & 0.98 & -0.03 & -0.05 \\
\hline Th & 0.93 & 0.15 & -0.01 & 0.13 \\
\hline $\mathrm{U}$ & 0.90 & 0.23 & -0.01 & 0.13 \\
\hline Expl. Var., \% & 17.9 & 8.96 & 4.71 & 3.05 \\
\hline
\end{tabular}



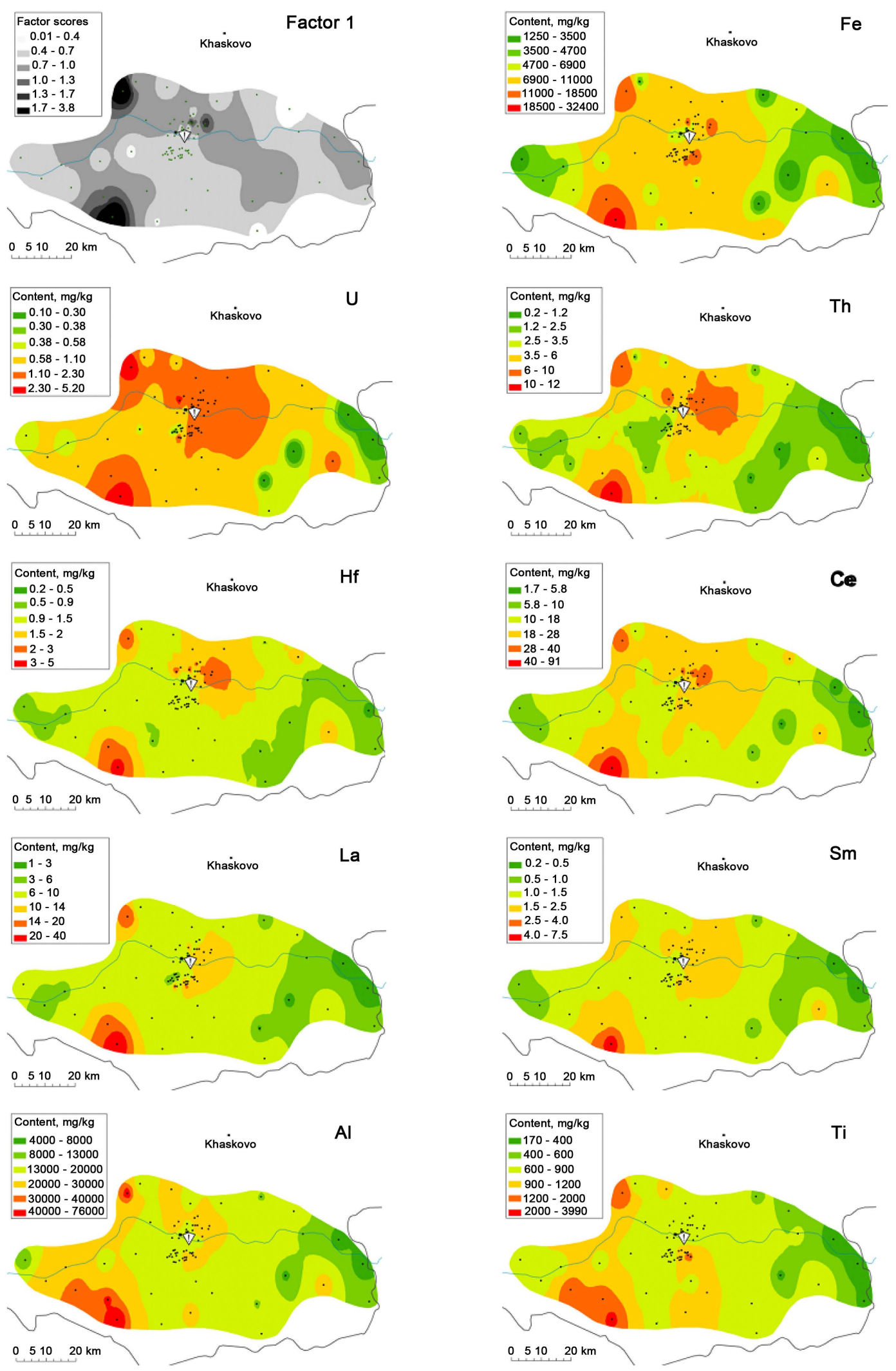

Figure 2. Spatial distribution of Factor 1 scores and atmospheric deposition patterns for Fe, U, Th, Hf, Ce, La, $\mathrm{Sm}, \mathrm{Al}$, and $\mathrm{Ti}$. 

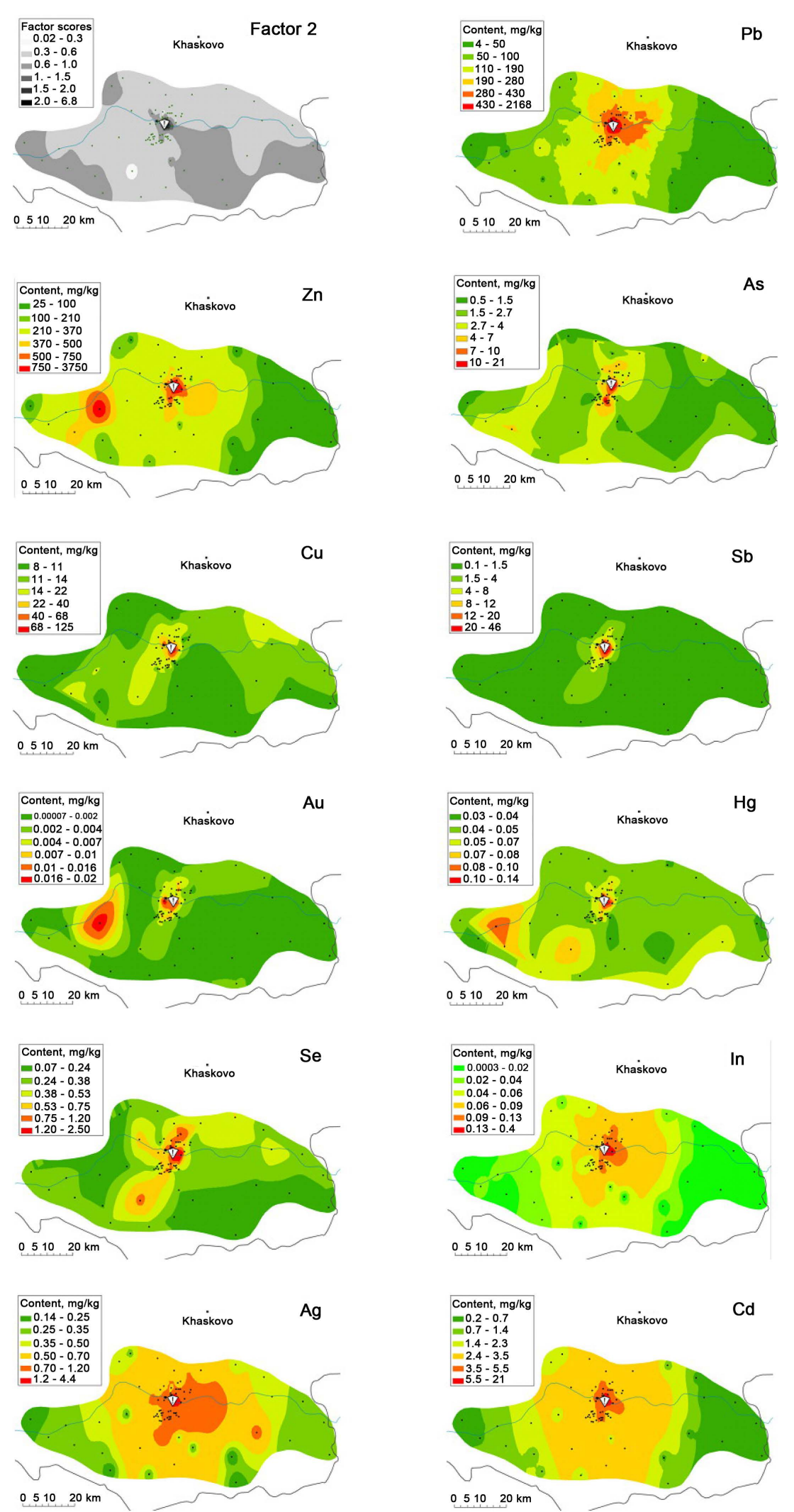

Figure 3. Spatial distribution of Factor 2 scores and atmospheric deposition patterns for $\mathrm{Pb}$, $\mathrm{Zn}, \mathrm{As}, \mathrm{Cu}, \mathrm{Sb}, \mathrm{Au}, \mathrm{Hg}$. Se, In, Ag, and Cd. 

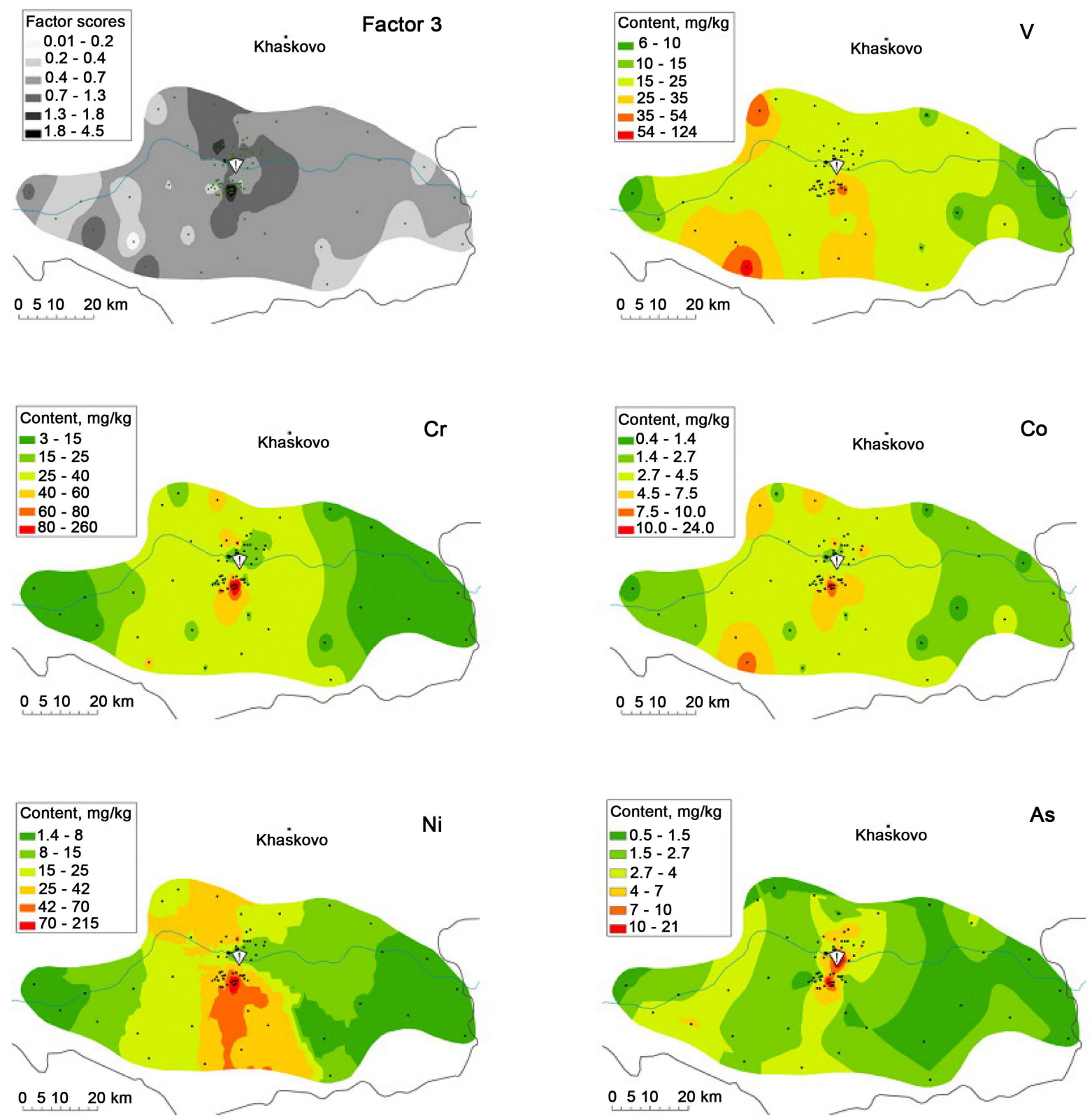

Figure 4. Spatial distribution of Factor 3 scores and atmospheric deposition patterns for V, Cr, Co, Ni, and As.

"marine" contribution to the air pollutants. The climate on the territory of the municipality is Continental Mediterranean [21] and is not influenced strongly by the proximity to the Back Sea. The north-south direction of the wind rose and the seasonal impact on the atmospheric circulation by the Aegean Sea agree with the marine interpretation.

\section{Conclusion}

Besides the well-known hazardous contaminants $\mathrm{Pb}, \mathrm{Zn}$, and $\mathrm{Cd}$ (first group of toxicity), elements posing a risk to the human health like $\mathrm{Se}, \mathrm{Ti}, \mathrm{Cr}, \mathrm{Cu}, \mathrm{Ni}, \mathrm{Al}, \mathrm{As}, \mathrm{Hg}$, and $\mathrm{Mo}$ (first, second and third groups of toxicity) were determined. The anthropogenic association of elements including Ag, As, $\mathrm{Au}, \mathrm{Cd}, \mathrm{Cu}, \mathrm{Hg}, \mathrm{In}, \mathrm{Pb}, \mathrm{Sb}, \mathrm{Se}$, and $\mathrm{Zn}$ presents typical group of elements in $\mathrm{Pb}-\mathrm{Zn}$ concentrates processed in the smelter plants as well in the produced metals. Therefore similar distribution patterns of element-pollutants for any lead-zinc plant may be expected taking into consideration the peculiarities of the landscape and productive capacity of the $\mathrm{Pb}-\mathrm{Zn}$ plant. The data 

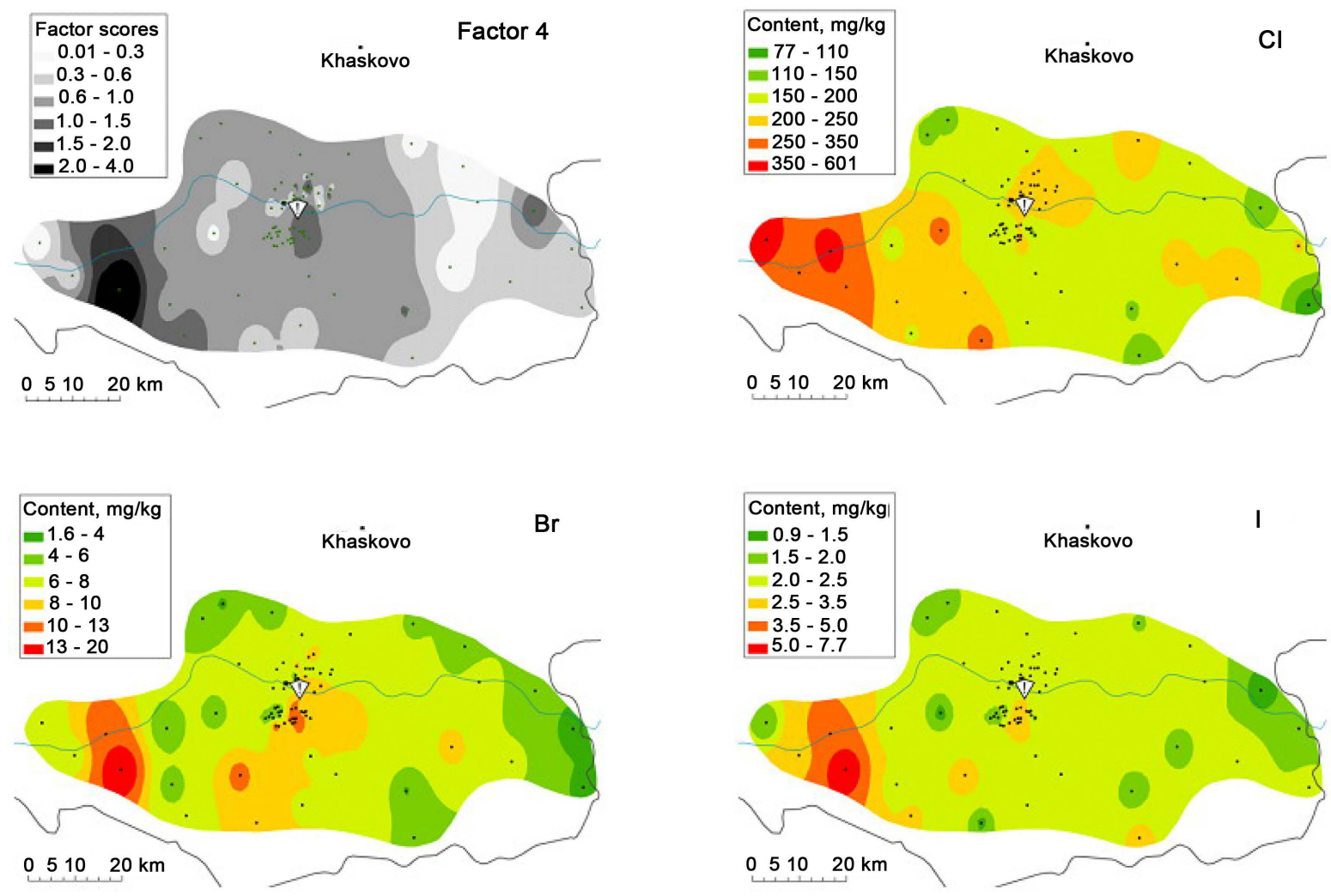

Figure 5. Spatial distribution of Factor 4 scores and atmospheric deposition patterns for $\mathrm{Cl}, \mathrm{Br}$, and I.

obtained, used in conjunction with the results from the state monitoring programs, could provide for a better estimation of health and environmental risk, and risk-management decisions. Moss biomonitoring surveys could be of great use as they provide a cost-effective and efficient means for a time-integrated assessment of the environmental situation and evaluation of anthropogenic changes.

\section{Acknowledgements}

The authors acknowledge the grant of Plenipotentiary of Bulgaria at JINR (JINR Order \# 245 of 14.04.2011) and express their gratitude to the Sector of Neutron Activation Analysis and Applied Research of FLNP JINR for their help in the experiments and to Prof. E. Steinnes for his advice in data interpretation.

\section{References}

[1] Rühling, Å. and Tyler, G. (1969) Ecology of Heavy Metals—A Regional and Historical Study. Botaniska Notiser, 22, 248-259.

[2] Čeburnis, D. and Vailiulis, D. (1999) Investigation of Absolute Metal Uptake Efficiency from Precipitation in Moss. Science of the Total Environment, 226, 247-253. http://dx.doi.org/10.1016/S0048-9697(98)00399-4

[3] Rühling, Å. and Tyler, G. (1973) Heavy Metal Deposition in Scandinavia. Water, Air, and Soil Pollution, 2, 445-455. http://dx.doi.org/10.1007/BF00585089

[4] Rühling, Å., Ed. (1994) Atmospheric Heavy Metal Deposition in Europe-Estimations Used on Moss Analysis. Nordic Council of Ministry, Copenhagen.

[5] Gjengedal, E. and Steinnes, E. (1990) Uptake of Metal Ions in Moss from Artificial Precipitation. Environmental Monitoring and Assessment, 14, 77-87. http://dx.doi.org/10.1007/BF00394359

[6] Harmens, H., Norris, D. and Mills, G. (2013) Heavy Metals and Nitrogen in Mosses: Spatial Patterns in 2010/2011 and Long-Term Temporal Trends in Europe. ICP Vegetation Programme Coordination Centre, WGE of the Convention on Long-Range Transboundary Air Pollution.

[7] Annual Reports (from 2007 to 2012) on Environmental Status in Haskovo and Kardzhali Districts. (In Bulgarian) 
http://haskovo.riosv.com/main.php?module=info\&object=info\&action=view\&inf_id=67

[8] The Bulgarian Association of the Metallurgical Industry, Official Statistics. (In Bulgarian) http://www.bcm-bg.com/index.php?MhObg5KvM5ODMZWfMRWHUNS3M5eLQVG-QtirkJSzIp

[9] (1994) Bulgaria: Environmental Strategy Update and Follow-Up, (World Bank No BUL 13493/USEPA/USAID). http://www-wds.worldbank.org/external/default/WDSContentServer/WDSP/IB/1994/12/30/000009265_39610070307 48/Rendered/PDF/multi0page.pdf

[10] Report on Environmental Impact Assessment, Lead \& Zinc Complex: Kardzhali. http://www.agaportal.de/pdf/nachhaltigkeit/eia/eia_bulgarien_zinkroesterei.pdf

[11] Ministry of Environment and Water of Bulgaria, Press Center, News. (In Bulgarian) http://www.moew.government.bg/?show=news\&nid=194

[12] Frontasyeva, M.V. (2011) Neutron Activation Analysis for the Life Sciences. A Review. Physics of Particles and Nuclei, 42, 332-378. http://www.springerlink.com/content/f836723234434m27/

[13] Barandovski, L., Frontasyeva, M.V., Stafilov, T., Šajn, R., Pavlov, S. and Enimiteva, V. (2013) Trends of Atmospheric Deposition of Trace Elements in Macedonia Studied by the Moss Biomonitoring Technique. Journal of Environmental Science and Health, Part A: Toxic/Hazardous Substances and Environmental Engineering, 47, 2000-2015. http://dx.doi.org/10.1080/10934529.2012.695267

[14] Balabanova, B., Stafilov, T., Bačeva, K. and Šajn, R. (2010) Biomonitoring of Atmospheric Pollution with Heavy Metals in the Copper Mine Vicinity Located Near Radoviš, Republic of Macedonia. Journal of Environmental Science and Health, Part A: Toxic/Hazardous Substances and Environmental Engineering, 45, 1504-1518. http://dx.doi.org/10.1080/10934529.2010.506097

[15] Barandovski, L., Cekova, M., Frontasyeva, M.V., Pavlov, S.S., Stafilov, T., Steinnes, E. and Urumov, V. (2008) Atmospheric Deposition of Trace Element Pollutants in Macedonia Studied by the Moss Biomonitoring Technique. Environmental Monitoring and Assessment, 138, 107-118. http://dx.doi.org/10.1007/s10661-007-9747-6

[16] Balabanova, B., Stafilov, T., Šajn, R. and Bačeva, K. (2014) Quantitavive Assessment of Metal Elements Using Moss Specied as Biomonitors in Downwind Area of One Lead-Zinc Mine. Journal of Environmental Sciences, 26, Early View.

[17] Berg, T., Røyset, O. and Steinnes, E. (1995) Moss (Hylocomium splendens) Used as Biomonitor of Atmospheric Trace Element Deposition: Estimation of Uptake Efficiencies. Atmospheric Environment, 29, 353-360. http://dx.doi.org/10.1016/1352-2310(94)00259-N

[18] Berg, T., Røyset, O., Steinnes, E. and Vadset, M. (1995) Atmospheric Trace Element Deposition: Principal Component Analysis of ICP-MS Data from Moss Samples. Environmental Pollution, 88, 67-77. http://dx.doi.org/10.1016/0269-7491(95)91049-Q

[19] Stafilov, T., Šajn, R., Pančevski, Z., Boev, B., Frontasyeva, M.V. and Strelkova, L.P. (2010) Heavy Metal Contamination of Surface Soils around a Lead and Zinc Smelter in the Republic of Macedonia. Journal of Hazardous Materials, 175, 896-914. http://dx.doi.org/10.1016/j.jhazmat.2009.10.094

[20] Steinnes, E., et al. (2007) Atmospheric Deposition of Heavy Metals in Norway, Nation-Wide Survey in 2005, State Program for Pollution Monitoring, Report 980/2007. Norwegian State Pollution Control Authority, Oslo. (In Norwegian)

[21] Sabev, L. and Stanev, S. (1959) Climatic Regions of Bulgaria and Their Climate, V. 5. Publishing House "Science and Art”, Sofia. (In Bulgarian) 
Scientific Research Publishing (SCIRP) is one of the largest Open Access journal publishers. It is currently publishing more than 200 open access, online, peer-reviewed journals covering a wide range of academic disciplines. SCIRP serves the worldwide academic communities and contributes to the progress and application of science with its publication.

Other selected journals from SCIRP are listed as below. Submit your manuscript to us via either submit@scirp.org or Online Submission Portal.
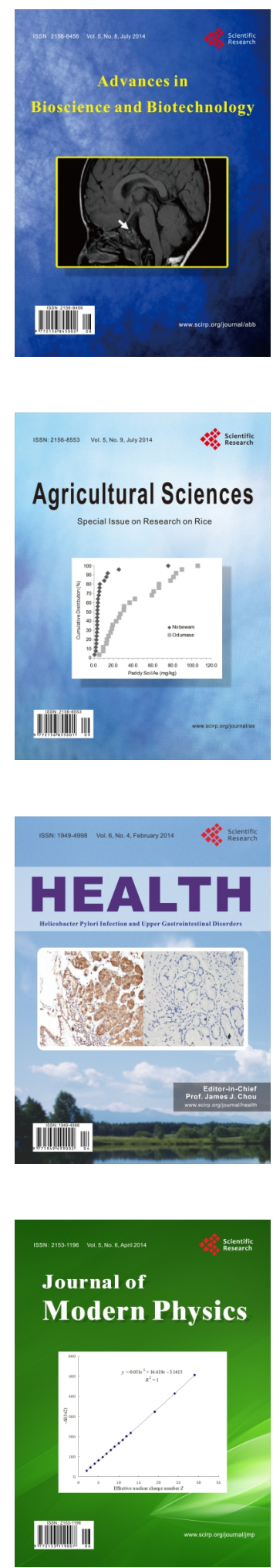
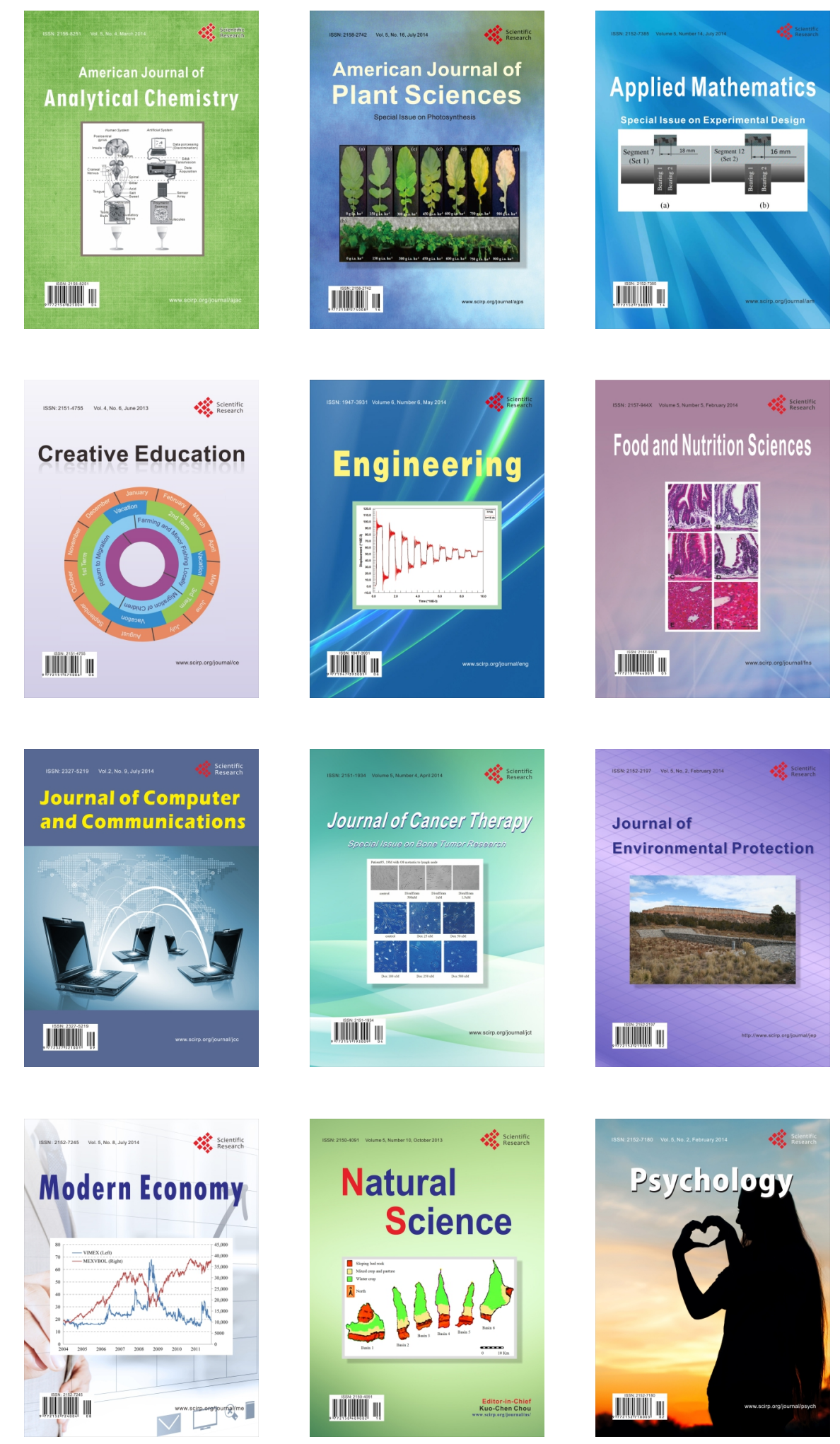